\title{
Regulatory Safeguards for Accountable Ecosystem Service Markets in Wetlands Development
}

\author{
Robert L. Glicksman*
}

\section{INTRODUCTION}

The use of market-based approaches to protect the environment has deep roots in the economics literature, dating at least as far back as A.C. Pigou's proposals to adopt pollution taxes. ${ }^{1}$ In the 1970 s, economists began arguing that U.S. environmental protection goals could be achieved more efficiently if the so-called "command-and-control" regulatory programs (referred to here as traditional regulatory programs) that were the foundation of laws such as the Clean Air Act (CAA) and the Clean Water Act (CWA) were replaced or supplemented with reliance on markets. ${ }^{2}$ If, for example, regulated entity $A$ could achieve pollution reductions more cheaply than regulated entity $B$, a system allowing $B$ to pay $A$ to reduce its pollution more than required so that $B$ would not have to comply with its own emission limit would result in more efficient pollution reduction than traditional regulation would. As long as $A$ 's excess reduction exceeds $B$ 's underperformance, at least the same amount of pollution is reduced as would occur under traditional regulation, but at a lower total. Moreover, such an emissions trading system provides incentives for those capable of reducing pollution at low cost such as $A$ to over-control because it is profitable for them to do so, as long as the revenue $A$ receives from $B$ is greater than the extra cost $A$

\footnotetext{
* J.B. \& Maurice C. Shapiro Professor of Environmental Law, The George Washington University Law School. This piece is based on a presentation delivered at the University of Kansas School of Law's November 1, 2013 conference on "Waters of the United States": Adapting Law for Degradation and Drought. The author thanks The Kansas Law Review for inviting him to present at the symposium conference and the other participants and audience members for useful feedback on his presentation. Many thanks also are due to Valérie Dupont, a Ph.D. candidate at the Université catholique de Louvain, for her very helpful suggestions. The piece's normative recommendations for creating accountable regulatory ecosystem service protection markets are derived from Robert L. Glicksman \& Thoko Kaime, A Comparative Analysis of Accountability Mechanisms for Ecosystem Service Markets in the United States and the European Union, 2 TRANSNAT'L ENVTL. L. 259 (2013).

1. Arthur Cecil Pigou, The Economics of Welfare (1920).

2. Wallace E. Oates, From Research to Policy: The Case of Environmental Economics, 2000 U. ILL. L. REV. 135, 136 (2000).
} 
incurs in generating excess reductions. ${ }^{3}$ Property rights proponents provided additional support for a shift toward markets, claiming that laws creating property rights in natural resources or in efforts to protect them would align the interests of property owners with the goals of environmental protection laws, to the benefit of all. ${ }^{4}$

The first calls for greater reliance on markets in environmental protection were met with skepticism by environmental public interest groups and some policymakers, who feared that participants could manipulate markets for private gain and mask noncompliance with regulatory obligations. ${ }^{5}$ Some even questioned the morality of creating tradable rights to pollute or otherwise damage the environment. ${ }^{6}$ Gradually, however, opposition to environmental markets weakened, and groups like the Environmental Defense Fund became champions of using markets to achieve environmental protection goals efficiently. ${ }^{7}$

The turning point came with the enactment of the 1990 CAA Amendments, ${ }^{8}$ whose acid deposition control title created a cap-andtrade program for coal-burning electric utilities that emit sulfur dioxide and oxides of nitrogen. Under that program, Congress doled out pollution "allowances" to regulated utilities, who were then free to meet their individual emission control obligations by reducing emissions to meet the cap, over-controlling and selling excess allowances to utilities unable or unwilling to meet their own obligations, or under-controlling and purchasing someone else's "excess" allowances. ${ }^{9}$ There is broad

3. See Perry S. Goldschein, Going Mobile: Emissions Trading Gets a Boost from Mobile Source Emission Reduction Credits, 13 UCLA J. ENVTL. L. \& POL'Y 225, 231 (1994/1995) (quoting Economic Incentive Program Rules, 59 Fed. Reg. 16690, 16716 (1994)) (explaining "emissions trading programs 'can lower the overall cost of meeting a given total level of abatement.' Facilities with lower cost abatement alternatives can provide the necessary emissions reductions to sources with more expensive alternatives; and all sources eligible to trade, including those already in compliance, face continuing incentives to further reduce emissions.").

4. See, e.g., Terry L. Anderson \& Donald R. Leal, Free Market Environmentalism 4 (rev. ed. 2001) (arguing that harnessing market forces will improve environmental quality).

5. See, e.g., David D. Doniger, The Dark Side of the Bubble, 4 The EnvTl. F. \# 3, at 33 (July 1985); Richard A. LiROFF, REFORMing Air Pollution REgulation: THE TOIL AND TROUBle of EPA's BUBBLE 62-67, 89-91 (1986) (describing flaws in early environmental market programs).

6. Richard J. LAZARUS, THE MAKING OF ENVIRONMENTAL LAW 183-84 (2004).

7. See, e.g., Environmental Defense Fund, How Cap and Trade Works, http://www.edf.org/ climate/how-cap-and-trade-works ("Cap and trade is the most environmentally and economically sensible approach to controlling greenhouse gas emissions, the primary driver of global warming."). See also Jason Plautz, Market approach to fighting pollution produces results - and compromises that set EDF apart, ENV'T AND ENERGY DAILY (Dec. 10, 2013), http://www.eenews.net/stories/ 1059991558 (explaining EDF's transforming views).

8. Clean Air Act Amendments of 1990, Pub. L. No. 101-549, 104 Stat. 2399 (1990).

9. Air Pollution Prevention and Control, 42 U.S.C. $\$ \S 7651(a)-(0)$ (2006). 
agreement that the acid deposition control program has worked well, achieving significant reductions in acid rain precursors at a lower cost than would have been possible without an emissions trading component, and at a lower cost than most observers predicted when the program was adopted. $^{10}$

As a result of the program's success, emissions trading has been built into other U.S. domestic environmental programs, as well as into international endeavors such as the Kyoto Protocol on greenhouse gas emission control. ${ }^{11}$ Ironically, when Congress considered the adoption of climate change legislation in 2009, it was the liberal Democrats and their environmental NGO allies, who initially had opposed the use of market mechanisms in environmental law, ${ }^{12}$ who most strongly supported the adoption of a cap-and-trade program for domestic emitters of greenhouse gases. Conservative Republicans adamantly opposed cap-and-trade, demonizing it by characterizing it as "cap-and-tax," even though it had been Republican politicians (including President George H.W. Bush) and their economist advisors who were largely responsible for the adoption of the acid deposition control program's cap-and-trade experiment. ${ }^{13}$

Despite opposition from one corner or another since their incorporation into environmental law, the role of market-based mechanisms has increased in recent years. Examples of permit or emission allowance trading regimes abound in U.S. environmental law, covering regulatory programs as diverse as renewable fuel production mandates, fuel additive reduction requirements, development of endangered species habitat, and intra-watershed pollution reduction. ${ }^{14}$

10. See Mark E. LeBel, Lack of Judicial CAIR: Chevron Deference and Market-Based Environmental Regulations, 20 N.Y.U. ENVTL. L.J. 277, 286-87 (2013) ("The Acid Rain Trading Program has largely been considered a success.").

11. See generally Toni Johnson, The Debate over Greenhouse Gas Cap-and-Trade, CounCIL ON FOREIGN RELATIONS, http://www.cfr.org/climate-change/debate-over-greenhouse-gas-captrade/p14231. Cf. Jessica Owley, The Increasing Privatization of Environmental Permitting, 46 AKRON L. REV. 1091, 1094, 1101 (2013) (discussing "a general trend of privatization" in environmental regulatory programs, including the dredge and fill permit program).

12. See supra note 5 and accompanying text.

13. See Thomas O. McGarity, EPA at Helm's Deep: Surviving the Fourth Attack on Environmental Law, 24 FORDHAM ENVTL. L. REV. 205, 225 (2012-2013) (“As greenhouse gas legislation languished in the Senate, the U.S. Chamber of Commerce and several grass roots organizations funded by energy interests attacked the [2009] House Bill as 'cap-and-tax' legislation.").

14. Robert L. Glicksman \& Thoko Kaime, A Comparative Analysis of Accountability Mechanisms for Ecosystem Services Markets in the United States and the European Union, 2 Transnat'L EnVtL. L. 259, 262-64 (2013). See also Royal C. Gardner \& Jessica Fox, The Legal Status of Environmental Credit Stacking, 40 ECOLOGY L.Q. 101, 104-21 (2013) (surveying 
They also have appeared under other nations' environmental programs, such as the European Union's Common Agricultural Policy. ${ }^{15}$ Some of these programs have worked well, while others have floundered, sometimes because robust markets have failed to develop and sometimes because participants have figured out ways to exploit the system, legally or illegally, in ways that undercut both efficiency and program effectiveness goals. ${ }^{16}$ The focus here is on the latter flaw, which has highlighted the need for the careful design of market-based programs to minimize opportunities for participants to exploit markets for financial gain at the expense of the broader public interest.

This article assesses the use of market-based programs with a trading component as a mechanism for protecting ecosystem services, which have perhaps been less thoroughly explored than emissions trading in pollution control regimes. It focuses by way of illustration on the use of markets to protect wetlands under the CWA's dredge and fill permit program. ${ }^{17}$ Part II describes the concept of ecosystem services and the use of environmental markets to preserve them. It also describes the CWA's regulatory framework for mitigating the adverse environmental consequences of wetlands development. Part III assesses the risks of relying on markets as environmental protection tools, providing several examples of abuses of such mechanisms that undermined the goals of the regulatory programs into which they were incorporated. Part IV recommends that any market-based environmental program include five critical safeguards to ensure accountability and minimize opportunities for abuse by both market participants and regulatory overseers. These include financial safeguards, verifiable performance standards, transparency and public participation safeguards, oversight mechanisms such as monitoring and inspections, and rule of law safeguards. Part IV also briefly assesses whether the wetlands mitigation component of the dredge and fill permit program relies on these safeguards in ways likely to promote efficient wetlands protection while minimizing opportunities for abuse that have plagued other environmental trading programs. It finds that the dredge and fill program has succeeded in incorporating effective accountability safeguards in some of these areas, but not others.

\footnotetext{
environmental regulatory markets under U.S. law).

15. See, e.g., Glicksman \& Kaime, supra note 14, at 264-66.

16. See infra Part III.

17. 33 U.S.C. $\$ 1344$ (2011). For discussion of the dredge and fill permit program, see 2 George Cameron Coggins \& Robert L. Glicksman, Public Natural Resources law $\S \S$ 19:15-19:25 (2d ed. 2007).
} 
Part V briefly concludes.

\section{ECOSYSTEM SERVICES, MARKETS, AND WeTLANDS PRESERVATION UNDER THE CLEAN WATER ACT}

Recognition of the services that nature provides to humans is increasingly being used to justify environmental regulatory programs. ${ }^{18}$ This Part introduces the concept of ecosystem services, describes how environmental markets may be used to protect these services, summarizes the CWA's dredge and fill permit program, and describes how that program relies on wetlands mitigation requirements, which are often market-based, to protect the flow of ecological services provided by well-functioning wetlands.

\section{A. The Value of Ecosystem Services}

In recent years, the value of healthy natural systems to humans has been increasingly recognized. These values are often referred to as "ecosystem services," or the benefits that people obtain from natural ecosystems. ${ }^{19}$ The value of preserving the flow of ecosystem services can justify environmental protection laws, and the concept can be used to rebut the oft-stated ${ }^{20}$ but erroneous claim that environmental protection inevitably comes at the expense of economic development. ${ }^{21}$ To the extent that environmental laws preserve valuable ecosystem services, they enhance, not detract from economic value.

Ecosystem services are often broken down into four categories: (1) supporting services, (2) provisioning services, (3) regulating services,

18. See, e.g., Barton H. Thompson, Jr., Ecosystem Services and Natural Capital: Reconceiving Environmental Management, 17 N.Y.U. ENVTL. L.J. 460, 464 (2008) ("Better information on the economic and social value of ecosystem services, for example, can help efforts to use ecosystem services to justify existing or new environmental regulations.").

19. 3 Millennium Ecosystem Assessment, Ecosystems and Human Well-being: POLICY RESPONSES, at vii (Kanchan Chopra et al. eds., 2005), http://www.maweb.org/ documents/document.772.aspx.pdf. See also Dale D. Goble, What Are Slugs Good For? Ecosystem Services and the Conservation of Biodiversity, 22 J. LAND USE \& ENVTL. L. 411, 422-24 (2007) (explaining and listing examples of ecosystem services).

20. See, e.g., Kevin Maurer, New Hanover officials worry pollution boundary could stymie development, STAR News ONLINE, Apr. 30, 2011, http://www.starnewsonline.com/article/20110430/ articles/110429601? p=2\&tc=pg (detailing county officials' concerns that environmental regulations will hurt the economy).

21. See, e.g., Adam Babich, Can Preemption Protect Public Participation?, 61 CASE W. RES. L. REV. 1109, 1139 (2011) (reporting that "many scholars believe that, on balance, environmental protection is good for economic development"). 
and (4) cultural services. ${ }^{22}$ As one scholar has noted, "[t]he concept behind ecosystem services is very simple - the environment offers critically important services for free that, if we had to pay for substitutes in markets, would command extremely high prices. Government policies that recognize this basic fact, and that [aim] to ensure and provide services, could result in increased social welfare.",23

\section{B. Protecting Ecosystem Services through Markets}

Market-based programs in ecosystem services seek to protect the value of these services from harm caused by development or pollution by taking advantage of the operation of markets through commodification of those services. These programs encourage people to think of conservation as a "private good" that benefits them, rather than as a "public good" requiring the support of governmental funding. ${ }^{24}$ They channel the benefits of environmental protection to landholders with control over the fate of the resources policymakers have decided are worth protecting.

Payments for ecosystem services can occur through business-tobusiness deals, the development of mitigation markets, the provision of government subsidies, or competitive grant programs. ${ }^{25}$ Landowners who agree not to develop resources which they control (and are otherwise allowed to develop free of legal constraint) receive development "credits," which can then be sold to regulated property owners. ${ }^{26}$ The purchasers can use the credits to satisfy regulatory obligations that otherwise would have precluded them from developing their own land. In short, "the value of the ecosystem products (services) is tied to a regulatory requirement to offset damages or measures to prove environmental performance." 27

22. James Salzman, What Is the Emperor Wearing? The Secret Lives of Ecosystem Services, 28 PACE ENVTL. L. REV. 591, 593-94 (2011) [hereinafter Salzman, Emperor].

23. James Salzman, Creating Markets for Ecosystem Services: Notes from the Field, 80 N.Y.U. L. REV. 870, 877 (2005).

24. Barton H. Thompson, Jr., Ecosystem Services \& Natural Capital: Reconceiving Environmental Management, 17 N.Y.U. ENVTL. L.J. 460, 475 (2008).

25. Salzman, Emperor, supra note 22, at 602-03.

26. See, e.g., id. at 599 (quoting Mike Johanns, Secretary of Agriculture for the Bush administration, on the future use of credits).

27. David Cooley \& Lydia Olander, Stacking Ecosystem Services Payments: Risks and Solutions, 42 ENVTL. L. REP. NEWS \& ANALYSIS 10150, 10151 (2012). 


\section{Protecting Wetlands to Preserve Ecosystem Services}

The value of healthy wetlands ecosystems was not appreciated until fairly recently. Wetlands, which once were commonly referred to as swamps or bogs, used to be regarded as foul smelling and unhealthy breeding grounds for mosquitos, vermin, and disease. ${ }^{28}$ They were also regarded as obstacles to economically beneficial development. ${ }^{29}$ Governments therefore made efforts to drain them, as quickly as possible. ${ }^{30}$ Both scientists and policymakers now realize that wetlands provide many valuable ecosystem services, including storm surge buffering, flood prevention, shoreline stabilization, soil retention, water purification, aquifer recharge, fish and wildlife habitat protection, and carbon absorption. ${ }^{31}$

Wetlands protection in the U.S. is driven largely by section 404 of the federal CWA, which created the dredge and fill permit program. ${ }^{32}$ Section 404 prohibits the development through dredging or filling of privately owned wetlands without a permit from the United States Army Corps of Engineers (Corps). ${ }^{33}$ The Corps must administer the section 404 permit program in accordance with guidelines developed by the federal Environmental Protection Agency (EPA), which also has the authority to veto individual section 404 permits. ${ }^{34}$ The Corps may not issue a permit if there is a practicable alternative to the proposed site that would have a less adverse impact on the aquatic ecosystem, or if permit issuance would not be in the public interest, based on a balancing of

28. Gardner \& Fox, supra note 14, at 105 ("Throughout most of this country's history, wetlands were viewed as wastelands or nuisances."); Thomas E. Dahl \& Gregory J. Allord, Technical Aspects of Wetlands: History of Wetlands in the Conterminous United States, National Water Summary on Wetland Resources, United States Geological Survey Water Supply Paper 2425, available at http://water.usgs.gov/nwsum/WSP2425/history.html.

29. Dahl \& Allord, supra note 28.

30. See generally John Copeland Nagle, From Swamp Drainage to Wetlands Regulation to Ecological Nuisances to Environmental Ethics, 58 CASE W. RES. L. REV. 787 (2008).

31. J.B. Ruhl, Ecosystem Services and Federal Public Lands: Start-up Policy Questions and Research Needs, 20 DuKE ENVTL. L. \& POL'Y F. 275, 275-76 (2010); see generally Thomas E. Dahl \& Susan-Marie Stedman, Status and Trends of Wetlands in the Conterminous United States 2004 to 2009, at 7 (2013), http://www.fws.gov/wetlands/Documents/Status-and-Trends-of-Wetlands-in-theConterminous-United-States-2004-to-2009.pdf. On the carbon absorption role of wetlands, see Linwood Pendleton et al., Considering "Coastal Carbon" in Existing U.S. Federal Statutes and Policies (The Nicholas Institute for Environmental Policy Solutions July 2012), http://nicholasinstitute.duke.edu/oceans/bluecarbon/considering-coastal-carbon-in-existing-u.s.federal-statues-and-policies\#.Up3q4tKmixo.

32. 33 U.S.C. $\$ 1344$ (2006).

33. $I d$.

34. Id. § 1344(c). 
project benefits and detriments. ${ }^{35}$

\section{Mitigation Markets and the Dredge and Fill Permit Program}

The Corps must condition any permit it issues on the taking of appropriate and practicable steps to minimize adverse impacts on aquatic ecosystems. ${ }^{36}$ Some land developers provide their own mitigation onsite, but the Corps allows section 404 permit holders to comply with their regulatory mitigation duties by participating in a form of emissions trading. Private entrepreneurs have created "banks" of wetlands which they have preserved so as to generate credits that can be sold to land developers. $^{37}$

As under other marketable permit and trading schemes, developers may meet their section 404 obligations by using the credits they purchase from such banks to compensate for (or offset) the wetlands they develop (and whose loss they do not otherwise mitigate). The commodity being exchanged is essentially liability because the effect of the transaction is to shift legal responsibility for compliance with regulatory mitigation duties from the permit-holding developer to the mitigation banker. ${ }^{38}$ In addition, this market-based program, like others, may be capable of achieving wetlands protection more efficiently than a system that does not allow the purchase and sale of credits because the banker can take advantage of economies of scale to provide relatively low-cost compensatory mitigation. ${ }^{39}$

Developers need not purchase mitigation credits from for-profit wetlands banks. They may instead meet compensatory mitigation requirements by purchasing credits from non-governmental organizations (NGOs) or by paying into an "in lieu" fee trust fund used to protect existing wetlands or create new ones. ${ }^{40}$ It is not unusual for NGOs to

35. 33 C.F.R. $\$ 320.4$ (2013); 40 C.F.R. $\$ 230.10$ (2013).

36. 40 C.F.R. $\$ 230.10$ (d). See also Gardner \& Fox, supra note 14, at 106 (describing the "avoidance-minimize-compensate" sequence under the dredge and fill permit program).

37. Owley, supra note 11, at 1097-98; Philip Womble \& Martin Doyle, The Geography of Trading Ecosystem Services: A Case Study of Wetland and Stream Compensatory Mitigation Markets, 36 HARV. ENVTL. L. REV. 229, 235-36 (2012).

38. Womble \& Doyle, supra note 37, at 249. "From the permittee's perspective, the benefit is certainty: fixed costs and no continuing legal responsibility." Gardner \& Fox, supra note 14, at 107.

39. See Owley, supra note 11, at 1110 ("Mitigation banks appear superior to individual projects because they are usually on larger parcels that are contiguous to other protected areas.... Mitigation banks enable consolidation of resources and planning and expertise.... Arguably, efficiency is increased with their use.").

40. Id. at 1098; see also Kentuckians for the Commonwealth v. U.S. Army Corps of Eng'rs, 
participate in environmental markets by, for example, purchasing credits and retiring them from the system. ${ }^{41}$ Wetlands mitigation markets have thrived. By 2009, several hundred wetlands mitigation banks were operating in the U.S., and wetland mitigation banking accounted for about a third of all regulatory mitigation conducted under the section 404 program. $^{42}$ By 2013, the Corps of Engineers had approved of more than 1300 mitigation banks. ${ }^{43}$

\section{THE RISKS OF ENVIRONMENTAL REGULATORY MARKETS: THREE EXAMPLES OF MARKET ABUSES}

The collapse of the savings and loan industry and of mortgage markets has made policymakers all too well-acquainted with the dangers of markets, especially in newly created, intangible or unfamiliar goods. ${ }^{44}$ The risk of manipulation and fraud is inherent in the operation of markets, and environmental regulatory markets are no exception. ${ }^{45}$ In various emissions trading markets, those who claimed to have produced and who then sold credits have been paid for making environmental improvements they would have made anyway (and even sometimes were already required to make), for "double-dipping" by making improvements for which they have already been fully paid at least once either in the same or another market, or for engaging in purely "paper trades" that are based on no real world environmental improvements at

No. 3:12-CV-00682-TBR, 2013 WL 4516774, at *17-19 (W.D. Ky. Aug. 23, 2013) (holding that the Corps complied with its regulations by requiring payment by section 404 permit holder to mitigation trust fund under in-lieu fee program); Lisa A. Wainger et al., Wetland Value Indicators for Scoring Mitigation Trades, 20 STAN. ENVTL. L.J. 413, 414 (2001) (“[L]and developers must either purchase credits from specific mitigation banks or pay into 'in-lieu fee' trust funds in order to receive permits to alter wetlands.").

41. See Jennifer P. Morgan, Note, Carbon Trading Under the Kyoto Protocol: Risks and Opportunities for Investors, 18 FORDHAM ENVTL. L. REV. 151, 159 (2006) ("NGOs also have an interest in utilizing the emissions trading market; NGOs can buy emissions credits and retire them, so they can never be used to allow domestic pollution by another purchaser.").

42. J.B. Ruhl, James Salzman \& Iris Goodman, Implementing the New Ecosystem Services Mandate of the Section 404 Compensatory Mitigation Program-A Catalyst for Advancing Science and Policy, 38 SteTson L. Rev. 251, 254-55 (2009); see also Owley, supra note 11, at 1109 ("Today, the majority of mitigation banks are private entrepreneurial ventures.").

43. Gardner \& Fox, supra note 14, at 108.

44. Cf. Victor B. Flatt, "Offsetting” Crisis?-Climate Change Cap-and-Trade Need Not Contribute to Another Financial Meltdown, 39 PEPP. L. REV. 619, 629-33 (2012) (comparing, but distinguishing the role of toxic assets in the financial crisis of 2009 and the potential for fraudulent manipulation of allowances under an emission trading program).

45. See id. at 638 (arguing that the need to check fraud in emissions trading programs "is little different from preventing fraud in any market system"). 
all (despite trumped up claims to the contrary). ${ }^{46}$ Although many of the most egregious examples of fraud have arisen under pollution control programs with market-based components, the risks are similar for ecosystem service markets such as the section 404 wetlands mitigation program.

It is not hard to find illustrations of how profit motives induce cheating that impairs environmental regulatory markets in the absence of regulatory safeguards. Three such examples are discussed here. First, in an effort to reduce the nation's dependence on foreign oil, help grow the nation's renewable energy industry, and reduce greenhouse gas emissions that contribute to climate change, the Energy Policy Act of $2005^{47}$ requires that transportation fuel sold in the U.S. be composed of at least a minimum volume of clean, renewable fuel. ${ }^{48}$ EPA regulations require petroleum refiners and importers (called "obligated parties") to demonstrate compliance with individualized Renewable Volume Obligations (RVOs). ${ }^{49}$ Obligated parties may comply with their RVOs by purchasing credits from renewable fuel producers, but they may not generate a credit for a fuel that is not a renewable fuel, or create or transfer to any person an invalid credit. ${ }^{50}$ Credits that are not based on the production of renewable fuel are invalid. ${ }^{51}$

EPA recently issued at least two dozen notices of violation to obligated parties alleged to have used invalid biomass-based diesel credits to comply with their RVOs. ${ }^{52}$ The credits were generated by a company that sold over 32 million credits, but that allegedly failed to produce even a single gallon of any renewable fuel. ${ }^{53}$ The company's owner was charged with wire fraud, money laundering, and violating

46. See Womble \& Doyle, supra note 37, at 291-92 (explaining that the lack of adequate regulatory oversight could allow mitigation providers to "double-dip").

47. Pub. L. No. 109-58, 119 Stat. 594 (2005).

48. 42 U.S.C. $\$ 7545(0)$ (2006); EPA, Renewable Fuel Standard (RFS), http://www.epa.gov/otaq/ fuels/renewablefuels/index.htm (last visited Feb. 16, 2014, 10:00 PM).

49. See generally EPA, Questions and Answers on Changes to the Renewable Fuel Standard Program (RFS2), http://www.epa.gov/otaq/fuels/renewablefuels/compliancehelp/rfs2-aq.htm (last visited Mar. 4, 2014, 5:16 PM).

50. 40 C.F.R. $\$ 80.1460$ (2013).

51. Id. $\$ 80.1431(\mathrm{a})(1)(\mathrm{vi})$.

52. EPA, Civil Enforcement of the Renewable Fuels Standard (RFS) Program, http://www2.epa.gov/enforcement/civil-enforcement-renewable-fuel-standard-program (last visited Feb. 16, 2014, 10:09 PM); see also Amanda Peterka, 2 Men Indicted in \$37M Biodiesel Fraud Schemes, GOVERNORS' BIOFUELS COALITION, http://www.governorsbiofuelscoalition.org/?p=8128 (last visited Mar. 19, 2014, 11:45 AM).

53. EPA, supra note 52 . 
federal environmental laws. ${ }^{54}$ It is not clear whether similar, additional scams under the renewable fuel credit program have gone undetected.

A second example of manipulation and fraud in environmental regulatory markets involves the intentional manufacture of a chemical (HFC-23) that is nearly 12,000 times more potent in its impact on climate change than carbon dioxide. ${ }^{55}$ The Clean Development Mechanism (CDM), the Kyoto Protocol's carbon credit trading program, values carbon credits according to the impact on global warming and the staying power in the atmosphere of particular greenhouse gases once they are emitted into the environment. ${ }^{56}$

One greenhouse gas, HFC-23, is a chemical byproduct of manufacturing refrigerants and feedstocks for certain plastic products. ${ }^{57}$ Between the initiation of the trading program and mid-2012, 46\% of all credits were awarded to coolant factories, mostly in developing countries. ${ }^{58}$ Asian companies in particular produced HFC-23 so that they could destroy it to generate credits that could be sold under the CDM. These companies had no interest in manufacturing coolants, and intentionally went out of their way to use inefficient manufacturing processes to generate as much waste HFC-23 as they could. ${ }^{59}$ Evidence of their business model is reflected in the fact that they shut down each year as soon as they sold the maximum amount of HFC-23 credits allowed under the program. ${ }^{60}$ But the adverse effects of this scam went beyond the intentional manufacture of a useless by-product. The companies produced so much coolant in their efforts to generate HFC-23 credits that the price of coolants fell, which discouraged air-conditioning companies from developing more efficient and less environmentally

\footnotetext{
54. Id.

55. See Elisabeth Rosenthal \& Andrew W. Lehren, Profits on Carbon Credits Drive Output of a Harmful Gas, N.Y. Times, Aug. 8, 2012, http://www.nytimes.com/2012/08/09/world/asia/ incentive-to-slow-climate-change-drives-output-of-harmful-gases.html?pagewanted=all\&_r=0. (describing the relative impact of HFC-23).

56. See generally Michael Wara, The Clean Development Mechanism's Performance and Potential, 55 UCLA L. REV. 1759 (2009) (explaining the Clean Development Mechanism).

57. Political Thaw Raises Hopes for Refrigerant Regulations, NATURE NEws BlOG (Apr. 26, 2013, 9:13 GMT), http://blogs.nature.com/news/2013/04/political-thaw-raises-hopes-for-refrigerantregulations.html; Ryan Cooper, What the Heck is HFC-23?, WASHINGTON MONTHLY, Aug. 9, 2012, http://www.washingtonmonthly.com/political-animala/2012_08/what_the_heck_is_hfc23039115. php.

58. Rosenthal \& Lehren, supra note 55.

59. Id.

60. Id.
} 
damaging alternatives to the coolant. ${ }^{61}$

A third example of marketable permits gone wild arose under a California air pollution emission-trading program. ${ }^{62}$ To combat persistent smog problems in southern California, state regulators adopted Rule 1610, also known as the car-scrapping program. ${ }^{63}$ Rule 1610 allowed emission trading between mobile and stationary sources, both of which emit ozone precursors that contributed to the region's longstanding noncompliance with the CAA's national ambient air quality standards. ${ }^{64}$ Rule 1610 allowed factories to avoid installing expensive pollution control equipment by purchasing pollution credits generated by destroying old, high-polluting cars (and measured by the projected avoided emissions from the destroyed vehicles). ${ }^{65}$ The basic idea was the same one that provides the foundation for all environmental regulatory markets - the potential to control environmentally damaging activity at a lower cost than traditional source-by-source regulation is likely to achieve. The trading program would induce the owners of highpolluting, older vehicles to take them off the road, which is likely a cheaper way to reduce emissions than by requiring factories to curtail smokestack emissions through technological fixes. ${ }^{66}$

The program was riddled with problems. Many of the cars whose destruction generated emissions credits were already destined for destruction for reasons having nothing to do with efficient pollution control. ${ }^{67}$ In addition, some of those who generated and sold credits by allegedly taking old vehicles out of circulation crushed the bodies of the cars but sold the engines for reuse in other cars still on the roads. ${ }^{68}$ As a result, the factories that purchased credits could legally emit more than their individual emission caps would have allowed in the absence of trading, but without any corresponding reductions in ozone precursor emissions through permanent removal of high-polluting vehicles from

\footnotetext{
61. Id.; see also Wara, supra note 56, at 1783-87 (explaining the incentive to generate HFC-23 credits).

62. See Richard Toshiyuki Drury et al., Pollution Trading and Environmental Injustice: Los Angeles' Failed Experiment in Air Quality Policy, 9 DuKE ENVTL. L. \& POL'Y F. 231, 235 (1999) ("The lessons learned from the Los Angeles pollution trading experiments should inform decision making in the development and reform of domestic and international emissions trading programs.").

63. Id. at 246.

64. 42 U.S.C. $\$ 7409$ (b) (2006).

65. Drury et al., supra note 62, at 246.

66. Id.

67. Id. at $261-62$

68. Id. at 261 .
} 
the road. Instead of achieving equivalent reductions at a lower cost, the trading program resulted in an increase in ozone precursor emissions. ${ }^{69}$

In short, market-based mechanisms create financial incentives to trade non-existent credits that cost nothing to generate. As Richard Toshiyuki Drury, legal director of Communities for a Better Environment (CBE), has explained, "trading programs create stronger incentives to manipulate the numbers and cheat, because credits that are fraudulently created are still worth money."70 This dynamic means that market-based environmental protection programs will achieve their goals of efficient and effective environmental protection only if they are designed in such a way as to enable the government bodies that administer them to identify, halt, and punish those who profit from phony reductions or otherwise game the system.

\section{Five Key Accountability SAFEguards}

Because markets in environmental amenities, like all markets, are subject to manipulation, market-based programs must be designed carefully. If they are not, the potential to achieve environmental protection goals more efficiently than more traditional regulatory approaches may not be realized. Further, the operation of poorly designed markets may subvert regulatory effectiveness. The prerequisites to well-functioning markets of any kind include a stable political environment, well-defined private property rights, and adequate financial support for proper administration. The absence of these background factors may induce a perception that a market is unpredictable and unreliable, which will impair trading and reduce its capacity to promote efficiency-inducing exchanges. ${ }^{71}$ An efficient and

69. Id. at 258-63; see also Nicklas A. Akers, New Tools for Environmental Justice: Articulating a Net Health Effects Challenge to Emissions Trading Markets, 7 HASTINGS W.-NW. J. ENVTL. L. \& POL'Y 203 (2001) (arguing that emissions credit systems can actually yield negative net health effects). For discussion of a car-scrapping program that achieved more mixed results, see Ted Gayer \& Emily Parker, Cash for Clunkers: An Evaluation of the Car Allowance Rebate System, ECON. STUDIES AT BROOKINGS 13 (Oct. 31, 2013), http://www.brookings.edu/ /media/research/ files/papers/2013/10/cash\%20for\%20clunkers\%20evaluation\%20gayer/cash_for_clunkers_evaluatio n_paper_gayer.pdf (concluding that the Obama Administration's "cash for clunkers" program "led to a slight improvement in fuel economy and some reduction in carbon emissions" and that it "was not a cost-effective way to reduce emissions," but that it was more cost effective than policies "such as the tax subsidy for electric vehicles or the tax credit for ethanol").

70. Drury et al., supra note 62, at 259; see also William H. Rodgers, Jr. \& Anna T. Moritz, The Worst Case and the Worst Example: An Agenda for Any Young Lawyer Who Wants to Save the World from Climate Chaos, 17 SOUTHEASTERN ENVTL. L.J. 295, 322-23 (2009).

71. See, e.g., Barton H. Thompson, Jr., Ecosystem Services and Natural Capital: Reconceiving 
effective market for protecting ecosystem services in connection with an environmental regulatory program, however, requires more to avoid exploitation that subverts regulatory goals. At a minimum, environmental regulatory markets should include a series of institutional safeguards that include financial responsibility requirements, verifiable performance standards, transparency and public participation standards, regulatory oversight mechanisms, and rule of law safeguards. The CWA section 404 wetlands mitigation trading program provides potentially effective versions of some, but not all of these accountability mechanisms.

\section{A. Financial Safeguards}

Traditional environmental regulatory programs often condition issuance of permits and other regulatory benefits on compliance with financial safeguards developed by agencies such as EPA. For example, the Resource Conservation and Recovery Act (RCRA), ${ }^{72}$ the federal statute that governs management of hazardous waste, requires evidence of financial responsibility (such as insurance) as a prerequisite to issuance of a permit to a facility that treats, stores, or disposes of hazardous waste. $^{73}$ Similarly, regulations issued under the Surface Mining Control and Reclamation Act (SMCRA), ${ }^{74}$ and by the multiple use agencies that grant permits to develop minerals on federal lands, require the submission of performance bonds before mining may commence. $^{75}$

Ecosystem services trading programs such as the CWA's wetlands mitigation banking program should include similar financial responsibility protections. ${ }^{76} \mathrm{CWA}$ wetlands banking rules do require the suppliers of credits to provide financial assurances such as performance

\footnotetext{
Environmental Management, 17 N.Y.U. ENVTL. L.J. 460, 483 (2008); Carlo Giupponi et al., A Pilot Study on Payment for Ecological and Environmental Services in Lashihai Nature Reserve, China, in PAYMENT FOR ECOSYSTEM SERVICES 110, 114 (Oxford Univ. Press ed., 2009) (listing key factors affecting the effectiveness of payment for ecosystem services schemes).

72. 42 U.S.C. $\$ \S 6901-6922 \mathrm{k}(2006)$.

73. Id. $\S 6924(\mathrm{a})(6) ; 40$ C.F.R. $\S \S 264.140-264.151$ (2013).

74. 30 U.S.C. $\S \S 1201-1328$ (2006); 30 C.F.R. $\S \S 800.1-800.70$ (2013).

75. E.g., 43 C.F.R. $\$ \S 23.9,3802.2$ (2013).

76. Cf. Victor Byers Flatt, This Little Piggy's Waste Goes to Market: The Bold New World of Non-Point Source Nutrient Trading and a Proposal to Bring Home the 'Real Reduction' Bacon, at 63-64 (May 24, 2013), available at http://papers.ssrn.com/sol3/papers.cfm?abstract_id=2269784 [hereinafter Flatt, Bold New World] (discussing insurance mechanisms included in unenacted federal greenhouse gas mitigation legislation); Flatt, supra note 44, at 641-42 (same).
} 
bonds, casualty insurance, letters of credit, or escrow accounts. ${ }^{77}$ Mitigation bankers must maintain a ledger to account for all credit transactions, and must notify the Corps of Engineers every time a credit transaction occurs. ${ }^{78}$ One additional safeguard that may be advisable would be to require that funds to be used for mitigation be placed in segregated trust accounts to minimize diversion of those funds for nonauthorized uses. $^{79}$

\section{B. Verifiable Performance Standards}

Most traditional U.S. environmental regulatory programs are built on a foundation of performance standards, which require regulated entities to achieve the level of pollution control or environmental protection needed to achieve regulatory goals, but afford those entities the discretion to choose how they will do so. ${ }^{80} \mathrm{~A}$ well-designed environmental market-based program should also incorporate standards against which to judge the performance of market participants, especially credit sellers. The agency responsible for administering a trading program must not only promulgate general rules that establish the minimum conditions for trading that will achieve desired levels of environmental protection, but also determine whether individual proposed trades satisfy those requirements and will actually provide the promised environmental services.

The tricky part is to strike a proper balance between creating a manageable set of rules and allowing for the smooth functioning of markets. Detailed rules can reduce flexibility and hamper useful trades.

\footnotetext{
77. 33 C.F.R. $§ 332.3(n)(2)(2013)$.

78. Id. $\S 332.8(\mathrm{p})(1)$.

79. Cf. 26 C.F.R. $\S 1.468 \mathrm{~B}-1$ (c)(3) (2013) (defining qualified settlement fund established by defendants in tort claim for tax purposes, in part, as one whose "assets are otherwise segregated from other assets of the transferor (and related persons)"); John J. Gutricha \& Fred J. Hitzhusen, Assessing the Substitutability of Mitigation Wetlands for Natural Sites: Estimating Restoration Lag Costs of Wetland Mitigation, 48 ECOLOGICAL ECON. 409, 422 (2004), available at http://ac.elscdn.com/S0921800904000151/1-s2.0-S0921800904000151-main.pdf?_tid=77e783e4-94c8-11e3-

afaf-00000aab0f6c\&acdnat=1392307627_70c1bc483e40d6e947d60c8a1c7495f6 (recommending requirement that wetlands development permittees post an interest accruing performance bond equal to the estimated foregone wetland benefits to provide incentives for more cost-effective wetlands restoration).

80. See Sidney A. Shapiro \& Robert L. Glicksman, Risk Regulation at Risk: Restoring A PRAGMATIC APPROACH 151-52 (Stanford Univ. Press 2003) (describing the difference between performance and design standards); Sidney A. Shapiro \& Robert L. Glicksman, Goals, Instruments, and Environmental Policy Choice, 10 DuKE ENVTL. L. \& POL'Y F. 297, 305-08 (2000)
} (same). 
In addition, extensive review of individual proposed trades will generate high transaction costs, blocking some beneficial trades that are too costly to arrange and implement. But the absence of regulatory detail and meaningful review of individual trades creates opportunities for abuse. ${ }^{81}$

The performance standards for wetlands mitigation trades under the section 404 program appear in Corps of Engineers regulations. ${ }^{82}$ Trading parties must prepare baseline inventories of historic and existing aquatic resources and identify immediate and long-term resource needs within watersheds that can be met through mitigation projects. ${ }^{83}$ In an effort to combat fraud, the regulations prohibit the same credits from being used to provide mitigation for more than one permitted activity. ${ }^{84}$ The regulations allow compensatory mitigation projects, where appropriate, to "be designed to holistically address requirements under multiple programs and authorities for the same activity." such "holistic" endeavors leave the program open to manipulation. The Corps's rules require identification of the parties responsible for implementation and long-term management of compensatory mitigation projects. $^{86}$

Permit applicants must prepare a mitigation plan to ensure long-term protection of the compensatory mitigation project site. ${ }^{87}$ Each plan must include a description of the legal arrangements and instrument, including site ownership, that will be used to ensure long-term protection of the mitigation project site; an adaptive management plan to address unforeseen changes in site conditions or other components of the mitigation project; and other information needed to determine the appropriateness, feasibility, and practicability of the compensatory mitigation project. ${ }^{88}$ The plan also must include performance standards that can be assessed using the best available science so that regulators may determine whether compensatory mitigation is providing the desired and expected wetlands functions, and is attaining applicable metrics

81. See generally James Salzman \& J.B. Ruhl, Currencies and the Commodification of Environmental Law, 53 STAN. L. REV. 607, 671-73 (2000) (discussing the pros and cons of both broad credit trade review and individual credit trade review).

82. 40 C.F.R. $\$ 230$ (2014).

83. 33 C.F.R. $\$ 332.3(\mathrm{c})(2)(\mathrm{iv})(2013)$.

84. Id. §332.3(j)(1)(ii).

85. $I d$.

86. Id. $\S 332.3(1)(1)$.

87. Id. § 332.4(c).

88. Id. 
(e.g., number of viable wetlands acres). ${ }^{89}$ These standards, which are supposed to be "objective and verifiable," may be based on measures of functional capacity described in terms of hydrological or other aquatic resource characteristics, or comparisons to reference aquatic resources of similar type and landscape position. ${ }^{90}$

The effectiveness of wetland mitigation efforts in general is far from clear. ${ }^{91}$ The dredge and fill permit program regulations allow restoration, establishment, enhancement, and preservation as mitigation strategies. ${ }^{92}$ However, not all of these options may provide equivalent levels of ecosystem services protection. According to some observers, "[r]estoration and enhancement projects have largely fared better than creation projects." 93 The National Research Council has recommended prioritizing restoration of existing degraded wetlands instead of creating new ones because restoration enhances chances for successful provision of ecosystem services. ${ }^{94}$ Therefore, any performance standards reflected

89. Id. $\S 332.5(\mathrm{a})$.

90. Id. §332.5(b).

91. See David Moreno-Mateos et al., Structural and Functional Loss in Restored Wetland Ecosystems, 10 PLOS BIOLOGY e1001247, at 6 (Jan. 2012), http://www.ncbi.nlm.nih.gov/pmc/ articles/PMC3265451/pdf/pbio.1001247.pdf ("If markets for ecosystem services and mitigation offsets from restored or created wetlands are used to justify further wetland degradation, net loss of global wetland services will continue and likely accelerate ...."); Robert W. Adler, The Decline (and Possible) Renewal of Aspiration in the Clean Water Act, 88 WASH. L. REV. 759, 791 (2013) ("Restoring or replacing wetlands values and functions is no easy task, however, and the efficacy of compensatory mitigation has been questioned from a scientific perspective."); Gardner \& Fox, supra note 14, at 106 ("Study after study has revealed problems with compensatory mitigation. Sometimes permittees simply ignored their obligation to provide wetland mitigation."). See also U.S. FISH AND Wildlife Service, Status and TREnds of Wetlands in the Conterminous United States 2004 TO 2009, at 72 (2013), available at http://www.fws.gov/wetlands/Documents/Status-andTrends-of-Wetlands-in-the-Conterminous-United-States-2004-to-2009.pdf (reporting that, notwithstanding some successful restoration projects, the net effect of wetlands mitigation creation and reestablishment efforts has been "loss of wetland diversity, hydrologic function, biological communities, and a 'homogenization of wetland landscapes"').

92. See 40 C.F.R. $§ 230.92$ (2013) (defining "compensatory mitigation" as "the restoration (reestablishment or rehabilitation), establishment (creation), enhancement, and/or in certain circumstances preservation of aquatic resources for the purposes of offsetting unavoidable adverse impacts which remain after all appropriate and practicable avoidance and minimization has been achieved").

93. Owley, supra note 11, at 1096. See also Martin W. Doyle \& Todd Bendor, Evolving Law and Policy for Freshwater Ecosystem Service Markets, 36 WM. \& MARY ENVTL. L. \& POL'Y REV. 153, 159 (2011) (noting that "the ecological values of [offset compensatory mitigation sites] were also often extremely low"). Professor Owley adds, however, that "restoration projects provide fewer acres and fewer functions than ecologists had predicted." Owley, supra note 11 at 1096.

94. Andrea B. Smoktonowicz, Comment, Federal Conservation of Wetlands Runs Amuck with Wetlands Mitigation Banking, 31 OHIO N.U. L. REV. 177, 186 (2005) (citing MARK S. DENNISON, Wetland Mitigation: Mitigation Banking and Other StRategies For DeVElopment and COMPLIANCE 120 (1997)) ("Not only have restoration projects been more successful, but also their 
in compensatory mitigation programs for wetlands development should reflect the relative chances of successful provision through available mitigation alternatives of the ecosystem services lost through development, based on the best available scientific knowledge. In addition, to hedge the risk that restored wetlands provided through mitigation will not fully and effectively replace the services provided by wetlands destroyed or impaired through development, developers should be required to achieve levels of performance that reflect a margin of safety, such as a requirement that restored or created wetlands amount to some multiple of the wetlands for which development is approved. ${ }^{95}$

\section{Transparency and Participation Safeguards}

According to the Millennium Ecosystem Assessment, "[i]nsufficient participation and transparency in planning and decision-making have been major barriers" to ecosystem protection, through market-based mechanisms and otherwise. ${ }^{96}$ Transparency is needed so that interested members of the public can gauge whether trades are consistent with regulatory goals and standards. ${ }^{97}$

The dangers of lack of transparency are illustrated by a rapid rise in the price of credits for the manufacture or importation of gasoline blended with ethanol or other renewable fuels in 2013. The market for these credits is connected to the renewable fuels standards adopted pursuant to the Energy Policy Act of 2005, discussed above. ${ }^{98}$ The price of ethanol credits jumped twenty-fold in 2013. ${ }^{99}$ Some attribute the steep

focus is on improving a degraded wetland as opposed to other methods, like creation or preservation, that do not focus on reestablishing an ecosystem.").

95. Cf. 42 U.S.C. $\$ 7503$ (a)(1)(A) (2006) (requirement in CAA that major stationary source to be constructed in area that has not yet attained the national ambient air quality standards more than offset its increased emissions with enforceable emissions reductions from other sources); Flatt, Bold New World, supra note 76, at 25 (proposing adoption of reserve ratio for nutrient trading to guard against natural disasters that prevent non-point sources of water pollution from generating promised credits for a point source).

96. 3 MiLLENNIUM ECOSYSTEM ASSESSMENT, supra note 19, at 3.

97. See Christie J. Kneteman, Building an Effective North American Emissions Trading System: Key Considerations and Canada's Role, 20 J. ENVTL. L. \& PRAC. 127, 127 (2010) (explaining that core attributes of an effective tradable market include transparency). See also Gardner \& Fox, supra note 14, at 142 ("Transparency is a critical feature for the credibility of any credit stacking program because it can contribute to public confidence that the markets are operating as they should and that the mitigation projects are providing appropriate offsets.").

98. See supra notes 47-51 and accompanying text.

99. Gretchen Morgenson \& Robert Gebeloff, Wall St. Exploits Ethanol Credits, and Prices Spike, N.Y. TimES, Sept. 14, 2013, http://www.nytimes.com/2013/09/15/business/wall-st-exploitsethanol-credits-and-prices-spike.html?pagewanted=all\&_r=0. 
rise to hoarding of credits by big banks and other financial institutions precisely at the time when the petroleum industry needed them most because they were reaching the limit of the amounts of ethanol that could be blended into gasoline without requiring the installation of new corrosion prevention systems. ${ }^{100}$

According to some observers, "[t]he market in ethanol credits is exactly the kind Wall Street loves: opaque, lightly regulated, and potentially very lucrative." ${ }^{\prime 101}$ In particular, EPA refuses to disclose information on the identities of traders or the amounts they buy and sell, even though the agency itself does not engage in the kind of fraud prevention oversight that is characteristic of regulators of securities and other financial markets. ${ }^{102}$ It also does not require disclosure by market participants themselves, citing the need to protect the confidentiality of refiners and other market participants. ${ }^{103}$ The steep rise in the price of renewable fuels credits may result in corresponding increases in the price of gasoline to consumers. ${ }^{104}$

One way to enhance transparency in wetlands development credits would be to create a publicly accessible registry that allows interested persons to track transactions. ${ }^{105}$ To remedy the absence of any centralized source of information on wetlands banking transactions, it may make sense to create a federal registry on environmental subsidies and trades, including wetlands mitigation transactions, and authorize citizen suits when required information is not submitted by participants or disclosed by the government. ${ }^{106}$ Other options include the creation of public boards with representatives of affected stakeholders to review and provide input on individual trades, citizens' juries, community issue groups, electronic democracy, focus groups, and consensus conferences. ${ }^{107}$

\footnotetext{
100. Id.

101. Id.

102. Id.

103. Id

104. Id

105. See Ecosystem MarketPlace, State of Watershed Payments: An Emerging MARKETPLACE 53-54 (Tracy Stanton et al. eds., June 2010), available at http://www.foresttrends.org/documents/files/doc_2438.pdf (discussing the creation of a registry as a potential infrastructure provider); Flatt, Bold New World, supra note 76, at 31-32 (discussing NutrientNet, an online system that enables nutrient trading programs to publish and obtain prices and facilitate public participation).

106. John C. Dernbach, Citizen Suits and Sustainability, 10 WIDENER L. REv. 503, 525 (2004).

107. Millennium Ecosystem Assessment, Ecosystems AND Human Well-Being, SYNTHESIS 99 (2005), available at http://www.maweb.org/documents/document.356.aspx.pdf.
} 
The Corps, with the assistance of EPA and the Fish and Wildlife Service (FWS), has developed an online tracking system, the Regulatory In Lieu Fee and Bank Information Tracking System (RIBITS). ${ }^{108}$ The Corps described RIBITS as a mechanism for providing

better information on mitigation and conservation banking and inlieu fee programs across the country. RIBITS allows users to access information on the types and numbers of mitigation and conservation bank and in-lieu fee program sites, associated documents, mitigation credit availability, service areas, as well [as] information on national and local policies and procedures that affect mitigation and conservation bank and in-lieu fee program development and operation. ${ }^{10}$

Early in the development of RIBITS, the Corps indicated its intent to integrate it with a global information system-enabled permit tracking data management system to further facilitate the tracking of spatial information associated with impacts and compensatory mitigation under the section 404 program. ${ }^{110}$ RIBITS is a restricted access site, however, ${ }^{111}$ limiting its value as a transparency device. Portions of the site are encrypted, requiring a multi-step process that requires the downloading of special software to gain access. ${ }^{12}$ In addition, there appear to have been delays in updating the system to include the latest information, and it has not included information on permittee-responsible mitigation. ${ }^{113}$

The agency supervising a regulatory program with a market-based component benefits from public participation, which can generate

108. See Welcome to RIBITS, U.S. ARMY CORPS OF ENG'RS, http://geo.usace.army.mil/ribits/ index.html.

109. Id.

110. Ruhl, Salzman \& Goodman, supra note 42, at 262 n.51.

111. Id.

112. Welcome to RIBITS, U.S. ARMY CORPS OF ENG'RS, http://geo.usace.army.mil/ribits/ index.html. See also RIBITS Background, U.S. ARMY CORPS OF ENG'RS, http://www.bwsr.state .mn.us/wetlands/wetlandbanking/General_RIBITS_ Instructions.pdf. A Corps Power Point presentation indicates that, as of May 2013, RIBITS was operational in 48 states. See Steven Martin, RIBITS and Stream Mitigation, at slide 3, U.S. ARMY CORPS OF ENG'RS (May 23, 2013), http://aswm.org/pdf_lib/stream_webinar/ribits_stream_ martin.pdf. For further background information on RIBITS, see Steven Martin \& Robert Brumbaugh, Entering a New Era: What Will RIBITS Tell Us About Mitigation Banking?, 33 NAT'L WeTLANDS NEWSLETTER 16 (May-June 2011), http://elr.info/sites/default/files/martin.pdf. For a video tour of RIBITS, see Becca Madsen, RIBITS Tour, VIMEO (2010), http://vimeo.com/11750345.

113. See Letter from Randy Wilgis, President, National Mitigation Banking Association, to Steve Martin (Feb. 5, 2013), http://www.mitigationbanking.org/pdfs/2013-02RIBITSletter.pdf (noting that several districts are not updating information on a timely basis). 
information about the costs and benefits of both general trading rules and individual trades of which the agency may not be aware. ${ }^{114}$ Public input on current and prospective uses of proposed wetlands development and mitigation sites, for example, may be valuable, so that the comparative merits and opportunity costs of developing alternative sites may be assessed. ${ }^{115}$ Public participation also tends to enhance legitimacy and social acceptance. ${ }^{116}$

The wetlands banking program fares well in terms of some aspects of public participation but not others. Compliance with the federal Administrative Procedure Act's (APA's) procedures for informal rulemaking ${ }^{117}$ should suffice to encourage and accommodate public input at the rules creation stage. Opportunities to provide input on individual trades is not always as good, but the CWA wetlands mitigation regulations require that the Corps provide public notice of (and solicit public comment on) a proposed permit, including a statement describing the amount, type, and location of any proposed compensatory mitigation, or indicate an intention to use an approved mitigation bank or in-lieu fee program. ${ }^{118}$ The regulations also provide a process for other federal and state agencies with environmental expertise to provide comments on proposed trades, and the Corps has created a dispute resolution process to resolve disagreements between the Corps and other agencies such as EPA or the FWS. ${ }^{119}$ Nevertheless, the difficulty of locating permits and associated documents concerning mitigation responsibilities and performance may undercut the legitimating and information enhancement roles that transparency and public participation are designed to play. ${ }^{120}$

114. See Rebecca M. Bratspies, A Regulatory Wake-Up Call: Lessons from BP's Deepwater Horizon Disaster, 5 Golden Gate U. ENVTL. L.J. 7, 59 n.345 (2011) ("Public participation and transparency are widely considered to be the backbone of legitimacy for public agencies.").

115. See Emily Hammond \& David L. Markell, Administrative Proxies for Judicial Review: Building Legitimacy from the Inside-Out, 37 HARV. ENVTL. L. REV. 313, 361 (2013) ("To the extent one prefers that processes be open to all, and believes that deliberations among a range of stakeholders is likely to better inform decisionmakers, greater transparency ... would facilitate more opportunities for the rich deliberation of many voices.").

116. See Stephen M. Johnson, Beyond the Usual Suspects: ACUS, Rulemaking 2.0, and a Vision for Broader, More Informed, and More Transparent Rulemaking, 65 ADMIN. L. REV. 77, 79 (2013) ("Broader, more informed, and more transparent public participation also increases the accountability of agencies and should instill a sense of legitimacy in the final rules that they adopt.").

117. 5 U.S.C. $\$ 553(b)-(c)(1981)$.

118. 33 C.F.R. $\$ 332.4(b)(1)(2008)$.

119. Id. §332.8(e).

120. See Owley, supra note 11, at 1122, 1126 ("It is not clear what a concerned citizen could do upon discovering a poorly operated mitigation bank. There are no avenues for public oversight or 


\section{Regulatory Oversight Mechanisms (Monitoring and Inspections)}

Access to key information is a prerequisite to effective oversight by either the government or the public. That access can take various forms, including mandatory monitoring, reporting, government inspections, and verification that the ecosystem services supposedly being provided actually are being provided. Without accurate monitoring data, the integrity of the allowance market is compromised. ${ }^{121}$ The Corps's section 404 regulations require each mitigation plan to contain monitoring requirements to help determine whether mitigation is on track to meet performance standards and whether mid-term adjustments through adaptive management are needed. ${ }^{122}$ Failure to submit required reports can trigger enforcement actions. ${ }^{123}$ Federal, tribal, state, and local resource agencies, and the public are entitled to copies of monitoring reports on request. ${ }^{124}$ The CWA regulations authorize the Corps to conduct site inspections at least annually to evaluate mitigation site performance. ${ }^{125}$

Whether these mechanisms work effectively in practice is another matter. The Government Accountability Office (GAO) concluded in 2005 that the Corps's guidelines for compliance inspections were vague on key issues such as how to determine whether mitigation is substantial and what information had to be included in reports. ${ }^{126}$ The GAO also found that, at least in districts it visited, the Corps performed limited oversight to determine the status of required compensatory mitigation, and it raised serious questions whether the Corps actually required permit holders to perform compensatory mitigation, required monitoring reports to be submitted, or conducted compliance inspections in accordance with

enforcement.").

121. Eileen Gauna, An Essay on Environmental Justice: The Past, The Present, and Back to the Future, 42 NAT. RESOURCES J. 701, 707-08 (2002) ("Unless there are adequate monitoring requirements [in environmental trading programs], it is difficult for the community or an enforcement agency to assess ongoing compliance and sue to enforce if necessary."); Flatt, Bold New World, supra note 76, at 16-17 (characterizing water quality monitoring to be an essential but costly necessity of a nutrient trading program).

122. 33 C.F.R. $\$ \S 332.4(\mathrm{c})(1), 332.6(\mathrm{a})(1)$ (2008).

123. Id. §332.6(c)(2).

124. Id. §332.6(c)(3).

125. Id. §332.6(a)(2).

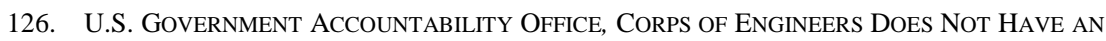
EFFECTIVE OVERSIGHT APPROACH TO ENSURE THAT COMPENSATORY MitigATION IS OCCURRING, GAO-05-898, at 4 (2005), http://www.gao.gov/products/GAO-05-898. 
regulatory schedules. ${ }^{127}$ Instead, the Corps largely relied on the good faith of permit holders to comply with compensatory mitigation requirements, rendering it frequently unable to assess whether compensatory mitigation had been performed. ${ }^{128}$ In some instances, the Corps did not even enter agreements with third-party sponsors to ensure the agency had legal recourse if compensatory mitigation was not being performed. ${ }^{129}$ The result was that some mitigation projects were unfinished and permit conditions were not met in some finished projects. ${ }^{130}$ According to a report by Resources for the Future, only about $20 \%$ of sites met the ecological equivalent of the displaced wetlands (using measures such as vegetative cover and hydrological function). ${ }^{131}$ As the GAO concluded, "[u]ntil the Corps takes its oversight responsibilities more seriously, it will not know if thousands of acres of compensatory mitigation have been performed and will be unable to ensure that the section 404 program is contributing to the national goal of no net loss of wetlands." 132

It is not yet clear whether revisions to the joint EPA-Corps's regulations adopted in $2008^{133}$ have adequately addressed these problems. ${ }^{134}$ At least one observer recently identified "[p]ervasive problems with monitoring, submitting reports, and performing long-term maintenance" by mitigation banks under the section 404 program. ${ }^{135}$ In the absence of adequate oversight, for example, "[t]here is a heavy reliance on good faith of [mitigation] bank operators."136 In such circumstances, there is a risk that regulators forfeit to market participants such as mitigation bank operators an inappropriate policymaking role. ${ }^{137}$

\footnotetext{
127. Id. at 5 .

128. Id. at 27

129. Id.

130. Id. at 25 .

131. Margaret Walls \& Anne Riddle, Biodiversity, Ecosystem Services, and Land Use: Comparing Three Federal Policies 9-10, RESOURCES FOR THE FUTURE (Feb. 2012), http://www.rff.org/RFF/Documents/RFF-DP-12-08.pdf.

132. U.S. GOVERNMENT ACCOUNTABILITY OFFICE, supra note 126, at 27.

133. Compensatory Mitigation for Losses of Aquatic Resources, 73 Fed. Reg. 19594-01 (Apr. 10, 2008).

134. See Adler, supra note 91, at 792 (“Although the new regulations include significantly stricter standards and procedures for compensatory mitigation, it is probably too early to evaluate how much better the new program will be in fulfilling CWA aspirations." (citation omitted)).

135. See Owley, supra note 11, at 1111 (noting the unavailability of monitoring reports, but citing sources that predate the 2008 regulations).

136. Id. at $1112-13$.

137. Id. at 1113. See also id. at 1115-16 (claiming that land trusts holding conservation easements are unburdened by monitoring requirements or other forms of government oversight); id.
} 
Notably, the EPA-Corps regulations appear to vest discretionary authority in the Corps's district engineers to determine whether and when to conduct inspections to evaluate mitigation site performance. ${ }^{138}$

Professor Lesley McAllister's work has shown that other kinds of operational safeguard systems are possible, such as third-party verification, but the government must oversee the verification bodies to ensure the accuracy of their findings and reports. ${ }^{139}$ The value of government oversight, either of mitigation banks and other participants in trades or of third-party verification bodies, will depend on whether the agency has adequate resources to review reports submitted by entities such as mitigation banks and conduct periodic inspections of wetlands mitigation sites. ${ }^{140}$ EPA and the Corps admitted in adopting the 2008 regulations that "[b]ecause of resource constraints, site visits cannot be conducted for each permit application. Districts must prioritize their site visits to determine which sites require on-site evaluations." ${ }^{141}$ Requiring

at 1125 ("Without consistent study and oversight, it is hard to know whether mitigation banks are delivering promised ecological benefits.").

138. See 40 C.F.R. § 230.96(a)(2) (2013) (“The district engineer may conduct site inspections on a regular basis (e.g., annually) during the monitoring period to evaluate mitigation site performance." (emphasis added)). See also Bonnie Malloy, Symbolic Gestures or Our Saving Grace: The Relevance of Compensatory Mitigation for Florida's Wetlands in the Climate Change Era, 27 J. LAND USE \& ENVTL. L. 103, 118 (2011) ("Heavy reliance on uncertain mitigation is exacerbated by the fact that the Corps has no mandatory duty to conduct inspections for compliance. Instead, compliance with mitigation requirements are specified in the permit conditions and the Corps generally relies on the permittee to provide reports - who often fail to comply." (citations omitted)).

139. See generally Lesley K. McAllister, Regulation by Third-Party Verification, 53 B.C. L. REV. 1 (2012) (arguing for greater government reliance on private auditors to achieve regulatory objectives); Lesley K. McAllister, The Enforcement Challenge of Cap-and-Trade Regulation, 40 ENVTL. L. 1195 (2010) (recommending a cooperative regulatory enforcement scheme, which includes participation by third-parties). See also Ruth Greenspan Bell, Culture and History Count: Choosing Environmental Tools to Fit Available Institutions and Experience, 38 IND. L. REV. 637, 652 (2005) (describing the "daunting logistical challenge of monitoring, reporting, and verification against fraudulent record-keeping or phony reductions," and arguing that "[ $t]$ he entire system collapses without a viable legal system or another institution to ensure the integrity of trades and to act in a timely manner to protect wronged parties").

140. Cf. Gardner \& Fox, supra note 14, at 141-42 (highlighting the need to provide agencies with the resources needed to confirm the ecological validity of market transactions in wetlands preservation).

141. Compensatory Mitigation for Losses of Aquatic Resources, 73 Fed. Reg. 19594-01, 19,609 (Apr. 10, 2008). Nevertheless, the agencies added that they "agree that vigorous enforcement and compliance activities are necessary for the success of the regulatory program, including compensatory mitigation. The Corps believes that it has adequate resources in these areas." Id. But see Royal C. Gardner, Rehabilitating Nature: A Comparative Review of Legal Mechanisms That Encourage Wetland Restoration Efforts, 52 CATH. U. L. REV. 573, 596 (2003) (noting that "some governmental agencies may lack the necessary appropriations to conduct rigorous monitoring" of privately conducted wetlands restoration efforts). 
bank sponsors seeking Corps approval to pay a fee may be a way to supplement government appropriations for these purposes. Some states have imposed such fees to cover the costs to state agencies of reviewing mitigation banking activities under state law analogues to the section 404 permit program. ${ }^{142}$

The discovery of flaws in another ecosystem-based market program highlights the need for monitoring and inspections to verify performance. The approval by the FWS of a landowner's habitat conservation plan can shield developers from enforcement of the Endangered Species Act's prohibition on taking of listed species. ${ }^{143}$ In exchange for the FWS's agreement to withdraw a proposal to list the sagebrush lizard as endangered, the state of Texas promised it would restrict surface disturbances in the lizard's habitat through such a plan. ${ }^{144}$ In May 2013, the state reported to the FWS that no surface disturbances were occurring. ${ }^{145}$ In June, the FWS Director praised the state's cooperation, indicating that the agreement was "the best outcome for the species." 146 Only two months later, a report from the Defenders of Wildlife documented through satellite images and aircraft photos that many potentially disruptive disturbances had occurred in connection with oil and gas development, including a forty-meter wide clearing running for several miles, new roads, and new or expanded drill pads. ${ }^{147}$

\section{E. Rule of Law Safeguards}

Accountability for noncompliance with the law by everyone involved in ecosystem service markets-including market participants and government officials who administer the program-is critical if

142. See, e.g., CAL. Fish \& GAME CODE $§ 1798.5$ (b) (West 2013); Conservation and Mitigation Banking, Laws and Policies, CAL. DEP'T OF FISH \& WILDLIFE, http://www.dfg.ca.gov/habcon/ conplan/mitbank/cmb_genpolicies.html (last visited Feb. 19, 2014) (chart describing fees required at each stage of the process of establishing a conservation or mitigation bank).

143. 16 U.S.C. $\$ \S 1538(a)(1)(B), 1539$ (a)(2) (2012).

144. See Phil Taylor, Texas Has Mismanaged Habitat Plan for Imperiled Lizard, E\&E News PM (Aug. 19, 2013, 4:52 PM), eandetv.com/eenewspm/2013/08/19/stories/1059986184 (detailing a report criticizing the state's handling of the habitat plan).

145. Id.

146. Id.

147. Ya-Wei Li et al., Habitat Disturbances Under the Texas Habitat Conservation Plan for the Dunes Sagebrush Lizard, DEFENDERS OF WILDLIFE (2013), http://www.defenders.org/sites/default/ files/publications/dunes-sagebrush-lizard-mapping-report.pdf; Glaring Mismanagement Found in Administration of Texas Imperiled Species Conservation Plan by State Comptroller, DEFENDERS OF WILDLIFE (Aug. 19, 2013), http://www.defenders.org/press-release/glaring-mismanagement-foundadministration-texas-imperiled-species-conservation-plan. 
manipulation and activities that subvert the ability to achieve section 404's goals are to be avoided. Judicial review provides one form of accountability. An accountable trading program should provide access to the courts for the review of the establishment of ground rules for trades, and of individual transactions for compliance with those rules.

Allowing citizen suits by environmental public interest groups or other stakeholders to enforce statutory and regulatory provisions such as monitoring and reporting obligations may be helpful. These suits can take one of two forms: a suit against a private entity alleging regulatory violations, or a suit against a government agency alleging failure to perform a nondiscretionary duty. ${ }^{148}$ The courts are divided on whether citizen suits may be brought under the CWA concerning the dredge and fill permit provisions in both contexts. Some courts have allowed citizen suits only against developers alleged to have discharged dredged or fill material into wetlands without a permit, ${ }^{149}$ but not against those alleged to have violated permit terms and conditions. ${ }^{150}$ The courts also disagree on whether the CWA waived the federal government's sovereign immunity to suits alleging violations of agency duties relating to the section 404 program. ${ }^{151}$

Meaningful sanctions are also an essential component of an accountable ecosystems services regulatory market. The creation of credible deterrents to minimize cheating in market-based trading programs is critical. ${ }^{152}$ These deterrents can result from authorizing the

148. On the latter, see generally Robert L. Glicksman, The Value of Agency-Forcing Citizen Suits to Enforce Nondiscretionary Duties, 10 WIDENER L. REV. 353 (2004) (outlining the history of citizen suits against the government for failure to perform nondiscretionary duties and discussing the costs and benefits of such suits).

149. See, e.g., Envtl. Def. Fund v. Tidwell, 837 F. Supp. 1344, 1350 (E.D.N.C. 1992).

150. See, e.g., Atchafalaya Basinkeeper v. Chustz, 682 F.3d 356, 358 (5th Cir. 2012) (per curiam); Nw. Envtl. Def. Ctr. v. U.S. Army Corps of Eng'rs, 118 F. Supp. 2d 1115, 1118-19 (D. Or. 2000). Cf. Owley, supra note 11 , at 1118-20 (pointing to examples of marginalized public participation and questionable accountability in privatized regulatory regimes, including uncertainty over whether citizen suits may be brought under the CWA against private contractors, despite permit holders having absolved themselves of responsibility through the purchase of mitigation bank credits or conservation easements).

151. Compare Avoyelles Sportsmen's League v. Marsh, 786 F.2d 631 (5th Cir. 1986) (allowing suit); Golden Gate Audubon Soc'y, Inc. v. U.S. Army Corps of Eng'rs, 717 F. Supp. 1417 (N.D. Cal. 1988) (same), with Preserve Endangered Areas of Cobb's History, Inc. v. U.S. Army Corps of Eng'rs, 87 F.3d 1242, 1249-50 (11th Cir. 1996) (sovereign immunity barred suit). Some courts that have concluded that suits may not be brought under the CWA have opined that suits under the APA may be available even if CWA citizen suits are not. See Cascade Conservation League v. M.A. Segale, Inc., 921 F. Supp. 692, 696-97 (W.D. Wash. 1996) (dictum) ("[T]he APA provides an alternate means of obtaining judicial review.").

152. Cf. Flatt, Bold New World, supra note 76, at 20-21 (discussing importance of enforcement 
imposition of financial penalties, the issuance of injunctions to shut down activities or require restoration, and the willingness to impose criminal sanctions for behavior such as willful misreporting. ${ }^{153}$ Simply having laws that authorize these sanctions is not enough, however. The government must adequately finance investigation and enforcement initiatives and government officials must retain their independence from those who would profit from flouting the rules.

An attractive option is to make a credit purchaser legally responsible for its seller's failure to meet performance standards or comply with other program requirements, so that someone other than the government has a stake in successful ecosystem protection actions. ${ }^{154}$ The Corps can assess administrative penalties for violating wetlands protection regulations or permits, require forfeiture of bonds, suspend or revoke permits, and recommend the imposition of harsher sanctions by the Department of Justice. ${ }^{155}$ Whether the Corps actually uses these powers effectively is a separate question. There is evidence that CWA enforcement actions brought by EPA and the states concerning pollutant discharges often fail to extract from violators the economic benefits of noncompliance. ${ }^{156}$ If Corps penalties suffer the same defect, slippage from regulatory requirements can be expected if it becomes more profitable to violate and pay penalties than it is to comply with regulatory obligations attached to trading authorizations.

\section{CONCLUSION}

Using markets to protect ecosystem services reflects both an increasingly popular methodology for structuring environmental policy and increased recognition of the importance of the natural environment

mechanisms for nutrient trading under the CWA).

153. Imposing financial sanctions on mitigation banks that the Corps has terminated for inadequate performance may be problematic, however.

154. Cf. Flatt, Bold New World, supra note 76, at 45-46 (discussing imposition of penalties on those in the business of producing nutrient trading credits for trades between point and nonpoint sources of water pollution); see also id. at 26 (noting that the Department of Agriculture regards transfer of regulatory liability from point to nonpoint sources of water pollution as beneficial because it reduces point sources' fear of the risks of trading).

155. See Jessica B. Wilkinson \& Robert Bendick, The Next Generation of Mitigation: Advancing Conservation Through Landscape-Level Mitigation Planning, 40 ENVTL. L. REP. 10023, 10036 (Jan. 2010).

156. See, e.g., Robert Glicksman \& Aimee Simpson, No Profit in Pollution: A Comparison of Key Chesapeake Bay State Water Pollution Penalty Policies (Ctr. for Progressive Reform Briefing Paper No. 1305, Apr. 2013), available at http://www.progressivereform.org/articles/No_Profit_ Pollution_1305.pdf. 
in providing a valuable flow of social benefits. The use of markets in ecosystem protection programs entails risks, however. Scientific knowledge gaps may allow trading participants to engage in abuses that escape the attention of regulatory overseers. The need for program elements that promote accountability-including financial safeguards, verifiable performance standards, transparency and public participation safeguards, oversight mechanisms such as monitoring and inspections, and rule of law safeguards - is therefore perhaps even more important than for other regulatory programs, such as some pollution control efforts that may be premised on better understandings of the causes and effects of environmental harms.

The final word on the efficacy of section 404 trades in protecting the ecosystem services provided by wetlands has yet to be written. The section 404 mitigation trading program has many of the elements of an accountable market device, but the agency's supervision and enforcement of compensatory mitigation plans appear to need improvements if the kinds of abuses that have occurred in other environmental markets are to be avoided, and congressional cuts in funding for environmental programs may hamper the ability of both EPA and the Corps to create effective deterrents to actions that undercut the program's protective goals. 